integrated into systems of husbandry capable of maintaining and enhancing fertility. Besides discussing the problem from the agricultural point of view, attention is also directed to the dangers of erosion around buildings, during construction of roads and in mining areas.

In order that measures for soil conservation shall be fully effective, communal action is called for, which may involve drastic modification in land utilization and agricultural practices. Some kind of legislation is therefore necessary. At present, the provisions for this vary widely in the different dependencies. In some it is built on the American model, whereas in others it is of a simpler form, or even based on the local rules of tribal or native authorities. A number of these provisions are described, those in operation in America being included for comparison.

\section{$12=$ \\ CARE OF FISH IN TRAWLERS}

$\mathrm{T}$

HE importance of fish, a home-produced protein food, cannot be prerstressed. To ensure that such a valuablo forty perishable food reaches the consumer as 1 esh and palatable as possible, care must be tren its treatment on board the fishing vessel as vil as after landing.

A lnes edition of "Food Investigation Leaflet No. 3, The Care of the Trawler's Fish" has recently been sublished for the Department of Scientific and Industrial Research by H.Vi. Stationery Office, price $4 d$. It is intended to help owners, skippers, mates and crews of trawlers and other vessels that catch 'white' fish to land their catches in the best possible condition. The leaflet, which has been revised and considerably extended, is concerned with the general practice of stowage in crushed ice.

The first section explains broadly and simply the scientific basis upon which the practical recommendations rest. Sea-water bacteria are the main agents of spoilage, bringing about the more striking undesirable changes in odour, flavour and appearance. These bacteria, simple types and harmless to man, are present in very considerable numbers on the outer surfaces, including the gills, of the gutted and washed, freshly caught fish, but not in the flesh. At ordinary temperatures, however, these bacteria multiply rapidly and invade the flesh, producing substances responsible for the stale, and later the putrid, odours and flavours associated with spoiling and spoiled fish, while the external surfaces become covered with dirty-coloured slime and lose their fresh bloom.

Practical recommendations are discussed in the second section. Chilling by stowage in crushed ice, although greatly retarding the activity of the bacteria, and hence spoilage, of the fish, does not stop it. Nevertheless, chilling is the most effective single factor in keeping fish fresh, and the greatest possible care should be taken to see that enough ice is used to chill the fish thoroughly and to keep it chilled until landing. In addition to controlling temperature, it is highly important to gut and wash the fish properly and to handle and stow it with care as soon as possible after catching, avoiding bruising, tearing or crushing. These principles hold good for all voyages, whether of a few days or of three weeks or even longer, as is now customary in the case of the distant-water vessels which provide more than half the fish supplies of Britain. The more fully they are observed, the better will be the general quality and acceptability of the fish.

A new feature of the leaflet is three appendixes. The first outlines the more important characteristics in the odour, appearance, texture, etc., of fresh and spoiled 'white' fish in both raw and cooked states. The second shows diagrammatically how, during stowage in ice for periods up to three weeks, the changing condition of the fish, as normally observed by the senses, is accompanied by increase in bacterial infection and in undesirable chemical changes in the flesh of the fish. The third appendix is a specimen short code of practice that might, it is suggested, be kept continuously before all concerned with the care of the fish.

The preservation of pelagic fish-namely, herring, pilchards and mackerel-is not dealt with in the pamphlet. So far as herring and pilchard are concerned, the problem of preservation scarcely arises on board, as the normal practice is to land the fish a few hours after they are caught. This, however, does not apply to the chief British mackerel fishery, in which the fish are often preserved on board in crushed ice for several days. In a highly perishable fish such as mackerel, great deterioration often takes place in a very short time. It would therefore seem worth while devoting some effort to devising for these fish, too, better methods of preservation on board and in land transit than are generally practised at present.

\section{FORTHCOMING EVENTS}

(Meeting marked with an asterisk * is open to the public)

\section{Monday, June 13}

ROYAL GEOGRAP CAL SOCIETY (at Kensington Gore, London, S.W.7), at 3 p.m. - Menal General Meeting.

\section{Monflay, June 13-Tuesday, June 14}

TruTI $\mathrm{N}$ OF GAS ENarneres (at the Institution of Civil Eng (eers, Great George Street, London, S.W.1).-86th Annua Genetal Meeting.

Tuesday, June 14

ZOOLOGICAL SOCIETY OF LONDON (at the Zoological Gardens, Regent's Park, London, N.W.8), at 5 p.m.--Scientific Papers.

\section{Wednesday, June 15}

PhYSICAL SOCIETY, COLOUR GRodp (at the Institute of Ophthalmology, Judd Street, London, W.C.1), at 4 p.m.-Dr. H. J. Plenderleith: "The History of Artists' Pigments".

Royal Meteorological Society (at 49 Cromwell Road, London, S.W.7), at 5 p.m. - Scientific Papers.*

Wednesday, June 15-Friday, June 17

INTERNATIONAL GaS UNION (at the Institution of Civil Engineers, Great George Street, London, S.W.1)-Fourth International Gas Conference.

Thursday, June 16

Royal SocIETy (at Burlington House, Piccadilly, London, W.1), at 4.30 p.m.- - Scientiflc Papers.

Instritution of Mining AND METalideray (at the Geological Society, Burlington House, Piccadilly, London, W.1), at 5 p.m.Discussion on "The Practical Postgraduate Training of Mining Engineers".

LONDON MAThEMatrcal Socretr (at the Royal Astronomical Society, Burlington House, Piceadilly, London, W.1), at 5 p.m.Prof. D. R. Hartree, F.R.S.: "Some Unsolved Problems of Numerical Analysis".

Royal Society of Tropical Medicine and Hygiene (at Mansen House, 26 Portland Place, London, W.1), at 7.30 p.m.-Annual General Meeting; Dr. R. V. Talice (Montevideo) will show a fllm dealing with Chagas' Disease.

Friday, June 17

BIochemical SocieTy (in the Department of Chemistry, The University, Nottingham), at 2 p.m. - Scientific Papers.

InstituTe of NAVigation (at the Royal Geographical Society, 1 Kensington Gore, London, S.W.7), at 5 p.m.-Discussion on "Astronomical Navigation in the Air". 